3. Назаренко А.В. Древняя Русь на международных путях: междисциплинарные очерки культурных и политических связей IX-XII вв. М.: Языки русской культуры, 2001. 784 с.

4. Плахонин А.Г. «История Российская» В.Н. Татищева и исследование генеалогии Рюриковичей // Средневековая Русь : [сб. ст.] / редкол.: А.А. Горский (отв. ред.) [и др.]; Рос. акад. наук, Ин-т российской истории. М.: Индрик, 2004. Вып. 4. С. 321-330.

5. Литвина А.Ф., Успенский Ф.Б. Внутридинастические браки между троюродными братьями и сестрами в домонгольской Руси // Древняя Русь. Вопросы медиавистики. 2012. № 3 (49). С. 45-68.

6. Либуркин В.Н. Проблема реальности существования близкородственных браков Рюриковичей в новейшей отечественной историографии [Электронный pecypc] // Современные проблемы науки и образования. 2015. № 1. - http://science-ducation.ru/ru/article/ view? id=18380.

7. Мейендорф Иоанн. Христианский брак в Византии: каноническая и литургическая традиция [Элек- тронный ресурс] // http://pravoslavie.ee/docs/christian marriage.pdf.

8. ПСРЛ. Т. 2. М.: ЯРК, 2001. 648 c.

9. Махновець Л.С. Літопис руський. К.: Дніпро, 1989. $591 \mathrm{c}$.

10. Татищев В.Н. История Российская. Т. 2. М.-Л.: Издательство Академии Наук СССР, 1963. 352 с.

11. Абуков С.Н. К вопросу о происхождении городенских князей // Вестник Нижегородского университета. 2016. № 3. С. 9-14.

12. ПСРЛ. Т. 1. М.: Языки славянской культуры. $2001.762 \mathrm{c}$.

13. Baumgarten N. Généalogies et mariages occidentaux des Rurikides Russes du X-e au XIII-e siècle // Orientalia Christiana. Roma, 1927. T. 35. 96 p.

14. Горбенко С.О. Ярослав Осмомисл. Реконструкція антропологічна та історична. Львів-Винники, 1996. $221 \mathrm{c}$.

15. Рапов О.М. Княжеские владения на Руси в $\mathrm{X}-$ первой половине XIII в. М.: Издательство Московского университета, 1977. $264 \mathrm{c}$.

16. ПСРЛ. Т. ХV (Вып. 1). М.: Наука, 1965. Стб. 41.

\title{
THE 7-TH DEGREE OF KINSHIP IN MARRIAGES WITHIN RURIKIDS IN THE XII CENTURY
} (C) 2016

S.N. Abukov, candidate of history sciences,

senior lecturer of Historiography, Source Studies, Archeology and Methods of History Teaching Department Donetsk National University, Donetsk (Donetsk People's Republic)

Abstract. The question of the political situation in Rus' in the XII century can not be considered in isolation from the relationship between the Rurikids. The marriages within dynasty of Old Russian princes, which played a very important role in the political relations of that period, were a part of political relations. However, there were religious prohibitions, which limited the possibility of such matrimonial alliances. Historians discuss about permissible in such cases, the degree of kinship in marriages. This article focuses on the role of the 7th-degree relatives in the dynastic marriages of Rurikids in the XII century. The author studied famous examples of conjugal unions between different lines of descendants of Yaroslav the Wise, and came to the deduction that such a degree of relationship was initially recognized as valid for the conclusion of such unions of ancient princes. At the beginning of the century, this tradition was connected with family of Vladimir Monomakh. Later it continued among the descendants as Monomakh and Oleg of Chernigov. During the second half of XII century within dynasty there were marriages of the 6th degree of kinship, but this practice was rather an exception. 7th degree of kinship remained closest to Rurikids in the future.

Keywords: prince; Kievan Rus; Rurikids; marriage; kinship; XII century; family ties; Vladimir Monomakh; Monomakhichy; Olegovichy; Roman Vladimirovich; Rurik Rostislavich; Vsevolodko of Goroden; Yaroslav Svyatopolchich; Vsevolod II of Kiev; Gleb Svyatoslavich; Davyd Olgovich.

УДК 9.94, 271-9, 271.5

\section{СТРАТЕГИИ АККУЛЬТУРАЦИИ: ПОЛИТИКА ФРАНЦИЗАЦИИ В КОНТЕКСТЕ ИЕЗУИТСКОЙ МИССИИ В НОВОЙ ФРАНЦИИ В ПЕРВОЙ ПОЛОВИНЕ ХVII ВЕКА}

(C) 2016

А.В. Федин, кандидат исторических наук,

доцент кафедры всеобщей истории, международных отношений и международного права

Брянский государственный университет им. академика И.Г. Петровского, Брянск (Россия)

Аннотация. Одной из главных особенностей французского колониального режима в Канаде XVII в. было формирование сложной и разветвленной сети союзов с индейскими племенами, основанной на взаимовыгодных экономических и военно-политических отношениях. В результате уже в первые десятилетия XVII в. виднейшие представители светской и духовной колонизации Новой Франции (Шамплен, реколлекты и иезуиты) приступили к разработке наиболее эффективных стратегий франко-индейского сближения и сотрудничества, воплотившихся к началу 30-х гг. в программе «францизации», то есть идеи аккультурации и ассимиляции аборигенного населения Канады французами как основного средства социально-экономического и политического развития колонии. Католические миссионеры, в том числе и члены иезуитского ордена, были заинтересованы в реализации этой программы на начальном этапе освоения новых территорий и становления колониальной инфраструктуры как материальной основы их деятельности по христианизации индейских народов. С этой точки 
зрения «цивилизация» индейцев по французскому образцу рассматривалась приоритетной по отношению к их христианизации. По мере расширения сети иезуитских миссий среди основных торговых и военных партнеров колонии и превращения иезуитского миссионера в главного посредника во франко-индейских отношениях к середине XVII в., с одной стороны, и роста противоречий со светской колониальной властью по широкому спектру проблем (включая торговлю алкогольными напитками) - с другой, иезуиты начали ревизию первоначальных положений программы «францизации», приведшую во 2-й половине столетия фактически к полному отказу от них и утверждению примата религиозного обращения над культурным.

Ключевые слова: католическая церковь; иезуиты; миссионерская деятельность; Новая Франция; Квебек; Акадия; североамериканские индейцы; алгонкины; гуроны; ирокезы; ассимиляция; аккультурация; аккомодация; францизация; колонизация; алкоголизм; эпидемии; мехоторговля; редукции.

Постановка проблемы в общем виде и ее связь с важными научными и практическими задачами. Одной из главных особенностей французского колониального режима в Новой Франции было формирование сложной и разветвленной сети союзов с индейскими племенами североамериканского Вудленда, основанной на взаимовыгодных экономических и военно-политических отношениях. Превращение мехоторговли в экономическую основу существования французской колонии в Квебеке в XVII в., с одной стороны, и слабая эмиграция французов из метрополии [1, p. $34 ; 2$, p. $246 ; 3$, p. $85 ; 4$, p. $41 ; 5$, p. 567,568$]$ - с другой, сделали эти союзы важнейшим фактором развития французской колониальной системы в Северной Америке вплоть до ее падения в середине XVIII в. Индейские племена были главными поставщиками пушнины на склады французских колониальных центров в Квебеке, Труа-Ривьер и Монреале, они же выступали главными (и единственными) союзниками французов в борьбе с враждебными племенами Ирокезской лиги, а позже - с английской экспансией на территорию колонии.

В результате уже в первые десятилетия XVII в. виднейшие представители светской и духовной колонизации Новой Франции приступили к разработке наиболее эффективных стратегий франко-индейского сближения и сотрудничества, воплотившихся к началу 30-х гг. в программе «францизации», то есть идеи аккультурации и ассимиляции аборигенного населения Канады французами как основного средства социально-экономического и политического развития колонии.

Анализ последних исследований и публикаичй, в которых рассматривались аспекты этой проблемы и на которых обосновывается автор; вылеление не разрешенных раньше частей общей проблемы. Одним из первых исследователей проблемы аккультурации канадских аборигенов в колониальный период был К. Жанен, который в своих работах очертил ее общие контуры и обозначил основных субъектов этого процесса $[6 ; 7 ; 8]$. В дальнейшем эту тему затрагивали в основном американские этноисторики (такие как Дж. Экстелл [9] или Дж. Ронда [10]), исследуя культурные контакты и их последствия для аборигенного населения североамериканского Вудленда в эпоху ранней колонизации (XVI-XVIII вв.). Правильно указывая на фигуру миссионера как на одного из главных проводников культурных изменений среди индейских народов, они тем не менее не рассматривали ни особенности аккультурационных стратегий представителей различных миссионерских групп в Новой Франции (реколлектов, иезуитов, сульпицианцев и т. д.), ни их эволюцию в контексте общих колониальных процессов, концентрируя внимание, прежде всего, на реак102 ции индейцев на культурные инновации. С другой стороны, историки католической миссии в Канаде (Г. Стэнли [11], Л. Кампо [12; 13]), давая исчерпывающую картину собственно миссионерских программ и практик с их теологическим и каноническим обоснованием, очень часто не вписывали их в общий контекст колониальных процессов.

Формирование целей статьи (постановка задания). Целью данной работы является уточнение изначальных взглядов французских миссионеров Общества Иисуса на способность туземного населения Канады не только к принятию христианской веры и образа жизни, но и «цивилизации» в ее европейской (французской) форме (францизации), а также эволюцию и ревизию этих первоначальных установок в условиях развития иезуитской миссии в первой половине XVII в. в Новой Франции. Позиция иезуитских миссионеров, одного из ключевых элементов французской колонизации, в отношении перспектив развития франко-индейских отношений, представляется важным для понимания специфики французской колониальной системы в Северной Америке.

Изложение основного материала исследования с полным обоснованием полученных научных результатов. В отличие от английских и голландских соседей, французы не считали métissage, то есть сексуальные и брачные отношения с представителями туземного населения Америки, чем-то недостойным и неприемлемым. Уже в XVI в., в период начального освоения французскими тресколовами и мехоторговцами канадского побережья, такие отношения не были редкостью [14, Vol. I. p. 118*]. В отсутствие интенсивной эмиграции из Франции, единственным способом заселения колонии оставалось естественное воспроизводство населения, а гендерный контекст колонизации вел к тому, что по преимуществу французы-мужчины вступали в отношения с индейскими женщинами. Самюэль де Шамплен, основатель и бессменный руководитель колонии в Квебеке, озвучил эту идею на большом совете с гуронами, главными торговыми и военными партнерами французов, в 1633 г.: «наши юноши возьмут в жены ваших дочерей, и мы станем одним народом» [15, Vol. V. p. 211].

Однако такой брак, с точки зрения официальных представителей светской и религиозной колонизации, мог быть возможен лишь с культурно релевантными партнерами. Для французов XVII в. культурно развитым, цивилизованным мог быть лишь представитель европейской христианской (католической) цивилизации, выраженной как в духовных аспектах (запечатленных в языке и поведенческих паттернах), так и внешних (одежда, жилище, диета и т. п.). Более того, речь шла не о европейских культурных ценностях раннего Нового времени вообще, а их региональном 
воплощении - французском обществе и государстве. Поэтому эталоном цивилизованного человека представлялся оседлый франкоязычный католический подданный французской монархии. И именно по такому образцу, воплощенном в формуле «иn roi, une foi, une loi», и следовало, с точки зрения идеологов французского колониализма, изменять природу и культуру американских индейцев, что и воплотилось в термине «францизация».

Впервые о францизации как официальной стратегии в развитии франко-индейских отношений было заявлено в уставных документах (хартиях) различных торговых компаний, которые с начала XVII в. получали от французской короны не только монопольные права на торговлю в Америке, но и статус феодальных собственников различных ее территорий. Так, хартия Генриха IV сьеру Пьеру де Мону, предоставлявшая ему в 1603 г. монополию на все территории Северной Америки, открытые и освоенные им, ставила условием этих привилегий «вызвать и пробудить их [индейцев] к знанию Бога и к свету христианской веры и религии». А герцог Монморанси, вице-король Новой Франции, еще более усилил инструкции короля, требуя от де Мона «стремиться привести туземцев к исповеданию христианской веры, к цивилизации манер, образцовой жизни, практике и общению с французами за выгоду от торговли с ними и, наконец, к признанию и подчинению власти и господству короны Франции» [16, Vol. II. p. 22; Vol. I. p. 217].

Хартия Компании Новой Франции 1627 г., подтверждавшая ее статус феодального собственника колонии и ставшая основным ее законом до 1663 г., одновременно ставила перед ней «цивилизаторские» задачи: главной целью организации колонии в Канаде провозглашалось «приведение народов, там живущих, к знанию истинного Бога, приобщение их к культуре и наставлении в вере». Единственным средством достигнуть этого было «населить названную страну урожденными французами-католиками, дабы их примером расположить эти нации к христианской религии, гражданской жизни, и так же установив там королевскую власть» $[17$, p. 5-6, 19]. Важным шагом в этом направлении явилось предоставление статуса французского гражданина не только любому белому ребенку, родившемуся в Канаде, но и любому окрещенному туземцу (ст. 17) [17, p. 10].

В 1635 г. Шамплен, провозглашая перед гуронами перспективы укрепления франко-индейских отношений путем métissage, уточнил, что «если они желают сохранить и усилить свою дружбу с французами, они должны принять нашу веру и поклоняться Богу, которого мы почитаем», а французы «женятся на их дочеpяx, когда те станут христианками» [15, Vol. VIII. p. 49]. Можно считать, что к этому моменту концепция «францизации» в самых общих чертах окончательно сформировалась: чтобы стать полноправными субъектами в колониальных отношениях, экономических и социальных, туземцы должны были стать подобны французам как во внутренних (духовных), так и внешних (материальных) проявлениях, то есть стать оседлыми земледельцами, принявшими не только религию, но и закон французского государства.

Католические миссионерские ордена в Новой Франции, реколлекты и иезуиты, полностью приняли эти установки стратегии светской колонизации в начале XVII в., считая их необходимыми условиями христианизации туземного населения. Помимо общей заинтересованности представителей церкви в росте и укреплении колониальной инфраструктуры как материальной основы их миссионерской деятельности, они исходили и из непосредственных задач апостолата. Столкнувшись с кочевым образом жизни индейских охотников, рыболовов и собирателей атлантического побережья Канады и долины р. Св. Лаврентия, миссионеры осознали, насколько это препятствует христианизации и созданию основ церковной организации среди них на основе посттридентских эталонов. Будучи кочевниками, «они не могут посещать, как положено, ни мессу, ни молитвы, ни публичные службы, ни проповеди, ни причастие, даже иметь священников. Как же вы думаете, смогут они утвердиться в вере и милости Божьей, если не получают наставления, причем необходимого вдвое больше, нежели для других?», - вопрошал в 1616 г. один из первых иезуитских миссионеров в Канаде Пьер Бьяр [15, Vol. III, p. 143]. Попытки сопровождать индейцев в их зимних кочевьях приводили миссионеров на грань смерти; недаром они уподобляли передвижение по канадским лесам и рекам и жизнь в индейских хижинах «малому мученичеству» [15, Vol. XVII, p. 13$15]$.

Выходом из этой ситуации могла стать именно такая стратегия цивилизации, которую разрабатывали Шамплен и ему подобные, подразумевающую переход к оседлому земледелию, по примеру французских колонистов. Таким образом, «доместикация», оседлый образ жизни индейцев становились основными условиями достижения спасения. «Если... остановить блуждание Дикарей, и дать власть одному из них, чтобы управлять другими, мы увидим их обращенными и цивилизованными в скором времени», - убеждал супериор иезуитской миссии в Квебеке о. Поль Лежён в 1637 г. [15, Vol. XII, p. 169. Cp.: Vol. XXII, p. 183185]. Материальным стимулом для этого стало предоставление осевшим на землю индейцам льгот на складах Компании при торговле мехами, возможность приобретать огнестрельное оружие только крещеным туземцам и пр.

Реколлекты, первые миссионеры в долине p. Св. Лаврентия, приглашенные в Квебек в 1614 г. именно Шампленом, полностью приняли его взгляды на франко-индейское взаимодействие в дискурсе «францизации». Помимо очевидной подчиненности первостепенным задачам светской колонизации, эта стратегия полностью укладывалась в августинианскоянсенистские представления, весьма популярные во Франции в первой половине XVII в., в том числе и среди католических орденов.

В отличие от томистских интерпретаций заальпийского католицизма, янсенизм был более пессимистично настроен в отношении способностей туземцев воспринять и христианство, и цивилизацию. Наиболее резко ее выразил Сен-Сиран: «Ни единой капли благодати не падает на язычников» [18]. С точки зрения августинианского богословия, естественный мир, с его дикостью, животными качествами, противопоставлялся разумной душе и духу цивилизованного человека. В естественном состоянии истинная доброде- 
тель была невозможна. Развитие в соответствии с природой рассматривалось как деградация. Обращение и цивилизация, таким образом, зависели от трансформации естественного до полного его подавления $[19$, р. $663 ; 20$, р. 48-49]. «Они заметили, - писал Шамплен о деятельности реколлектов, - что никогда не преуспеют в обращении [туземцев], если, прежде чем сделать их христианами, не сделают их людьми. Необходимо сделать индейцев оседлыми и привести их к нашим обычаям и законам», «так, чтобы с французской речью они могли также приобрести французское сердце и дух» [21, Vol. II, p. 340; 22, Vol. I, p. 110-111; 23, Vol. III, p. 6].

Вслед за реколлектами, первые иезуиты в долине р. Св. Лаврентия видели в местных аборигенах только естественный материал, который еще необходимо было обработать, «дикарей» превратить в настоящих людей. С этой целью первый настоятель иезуитской миссии в Квебеке П. Лежён разработал программу обращения канадских индейцев. Вся третья глава его Реляции 1634 г., называвшаяся «О средствах обращения дикарей», была посвящена ей. Вплоть до 40-х гг. эта программа будет определять ход всего иезуитского апостолата в Канаде, претерпевая лишь незначительные изменения.

Во-первых, помимо прочего, супериор заявлял о привлечении кочевых племен к оседлой жизни как необходимом условии их христианизации: «мы будем работать много, а продвигаться очень мало, если не сделаем этих варваров оседлыми» [15, Vol. VI, p. 149]. Здесь, однако, наблюдалась определенная ревизия тех принципов конверсии, которые иезуиты разделили с реколлектами, прежде всего, представления о фактически автоматической «цивилизации» индейцев в результате лишь одного присутствия европейцев. Некоторые, замечал Лежён, «воображают, что если сюда прибудут несколько [французских] семейств, Дикари последуют примеру наших французов и осядут, чтобы обрабатывать землю. Я сам был увлечен этими идеями, когда мы впервые прибыли сюда; но общение с этими народами и трудности, с которыми эти люди встретятся при занятии столь тяжелым трудом, как возделывание земли, заставляет меня считать теперь, что, если им не помочь, они падут духом» [15, Vol. VI, p. 151].

Второй вывод, сделанный Лежёном, заключался в осознании невозможности заставить взрослых туземцев оставить их языческую практику. Главное внимание было необходимо перенести на младшее поколение: «Мы ожидаем больше плода от молодых растений, - позже напишет Лежён, - чем от старых деревьев, почти полностью гнилых» [15, Vol. XI, p. 221]. C этого времени создание семинарий «для маленьких мальчиков, а со временем... для девочек», которые были бы «наставлены здесь со всей свободой, будучи отделенными от своих родителей», становится еще одним важным средством христианизации для иезуитов [15, Vol. VI, p. 83-85, 151-153]. Такая семинария изолировала бы молодое поколение от их традиционного образа жизни, от связей с поколением старшим, хранителем этой преемственности традиций, и тем самым облегчала обращение молодежи и создание из нее в перспективе христианского населения [15, Vol. VI, p. 83].
Иезуиты были согласны и с поощрением межрасовых браков, хотя подходили к этой проблеме с сугубо религиозных позиций. Составленный ими совместно с клерками Компании Новой Франции в 1635-1636 гг. документ «Причины, дозволяющие браки французов с туземными женщинами», был написан в духе шампленовской «францизации», но содержал положения, в перспективе ведшими к иной трактовке роли métissage в отношениях с туземцами.

Если Компания видела в межрасовых браках средство привлечения к постоянному жительству в колонии ее работников, в своем большинстве холостых мужчин, средство укрепления франко-индейских отношений на основе родства и увеличение населения колонии, то миссионеры, прежде всего, видели в них средство христианизации. Они считали, что браки французов и индианок сильнее свяжут колонистов с миссионерами, ибо те не только будут освящать эти браки, но и крестить и наставлять их жен. Межрасовые браки также выступали средством привлечения родственников индейских жен к цивилизованной и христианской жизни, что вело к «сокращению количества дикарей и увеличению числа христиан, тем более, что все их дети будут крещены, если же они останутся дикарями, то и они будут дикими». Извращения веры не должно опасаться, ибо в обществе французского мужа и отца ни жена, ни дети не отпадут от истинной религии [14, Vol. III, p. 36-39].

Но оставался вопрос: допустим ли брак христианина с язычницей, даже с целью ее обращения? Генерал ордена Муцио Вителлески, которому был послан этот документ, ответил однозначным отказом в 1638 г. [14, Vol. IV, p. 20]. Возможно, это было начальной точкой отсчета в ревизии программы «францизации» в ее первичном варианте. Если для реколлектов и Шамплена первичной была именно «цивилизация» («францизация») туземцев как основа христианизации, и с этой точки зрения брак с неверной дикаркой представлялся эффективным путем приближения к французским образу жизни и вере, то иезуиты начали выдвигать на первый план именно религиозный аспект: вера прежде культуры, обращение перед супружеством.

Представляется, что до конца 1630-х гг. иезуитские миссионеры в Новой Франции в общих чертах следовали общему цивилизаторскому дискурсу. Но по мере распространения сети иезуитских миссий среди индейских племен Северо-Востока и более глубокого понимания их членами образа жизни и религиозных представлений туземцев, с одной стороны, и роста противоречий с колониальной администрацией относительно стратегии отношений с индейцами - с другой, иезуиты постепенно трансформировали первоначальные установки конверсии, считая приоритетным религиозное обращение перед цивилизацией.

Смерть Шамплена в конце 1635 г. означала для иезуитов новый этап развития их апостолата в Канаде. С этого времени тенденция к отказу от некоторых элементов программы «францизации», главным апологетом которой был именно Шамплен, развивалась уже без препятствий, приведя к 1640 г. к серьезной модификации этой программы и всего иезуитского миссионерского предприятия в целом. Увеличение населения колонии к этому времени и интенсифика- 
ция контакта с соседними индейскими племенами монтанье и алгонкинами породили проблемы алкоголизма и распущенности среди индейцев, сведя на нет усилия миссионеров в их христианизации. Первые признаки беспокойства по поводу тлетворного влияния европейской цивилизации на индейцев, выражавшегося, в том числе, в распространении пьянства, появились в иезуитской среде уже в середине 30 -х гг., по мере укрепления и роста французской колонии.

Уже в 1635 г., когда Новая Франция состояла лишь из одного Квебека, в котором проживало менее 200 человек $[24$, p. 75$]$, иезуитские миссионеры начинают испытывать беспокойство по поводу моральных качеств прибывавших поселенцев. «Нужно опасаться того, - писал тогда о. Лежён, - что при увеличении наших французов в этих странах, мир, счастье и доброе чувство могут не увеличиться» в равной мере. Поэтому сюда нельзя допускать «порочных людей, ибо они построят Вавилон» [15, Vol. VIII, p. 9].

В 1636 г. о. Лежён, еще будучи уверенным, что «быть Варваром и добрым христианином, жить как Дикарь и как дитя Бога две абсолютно разные вещи», впервые выразил разочарование в установках «францизации», сместив акцент с культурных аспектов к религиозно-нравственным: «Я больше желаю видеть эту страну очищенной, чем населенной» [15, Vol. IX, p. 91, 191]. Выражая вполне адекватные шампленовским проектам чувства, он писал о том, что «чем больше слава французов продолжит увеличиваться в этих землях, тем больше... Дикари станут восхищаться силой, изобретательностью и нравственностью наших французов, что составит большую часть их веры и заставит с большей готовностью принять ее». Тем не менее он позволил себе допустить сомнение в этом, добавив: «я дрожу при написании этих слов, так сильно я боюсь разочароваться в этом ожидании», ибо французские поселенцы представлены «как лучшими и избранными душами, так и воистину низменными и худыми», обучающими туземцев не благочестию, а воровству и пьянству. «И кто бы ни поступал так, он проливает кровь Иисуса Христа, которому он препятствует войти в эти бедные души» [15, Vol. IX, p. 97; Vol. XI, p. 63, 75]. Выражая в 1637 г. удовольствие по поводу растущего числа колонистов, Лежён, однако, замечал, что среди них присутствуют «распущенные люди, которые шокируют Дикарей своим грубым языком... и всегда пьяны», и тем самым дискредитируют деятельность миссионеров. Но он еще был уверен, что «это недостатки очень немногих людей, и не имеют никаких последствий» [15, Vol. XI, p. 75].

Однако реальные успехи цивилизационной программы были весьма незначительны. Лишь несколько индейцев согласились на совместное проживание с французами и на работу на земле. Известен лишь один случай, когда этот опыт был расценен миссионерами как положительный, - семья индейцев монтанье во главе с Ля Нассом, которого иезуиты еще в период I Квебекской миссии (1625-1629 гг.) смогли привлечь к культивации почвы, выделив ему участок на своей земле [23, Vol. VI, p. 49-50]. С другой стороны, известно о конфликтах, возникавших между колонистами и аборигенами, приводящих к их отказу от «францизации» [15, Vol. IX, p. 19]. Возможно, именно поэтому иезуиты приступили к реализации собствен- ной программы, опирающейся на опыт их коллег в Ибероамерике - программы создания редукций, т. е., поселений обращенных индейцев на территории колонии. Уже к 1637 г. была создана первая такая редукция в Сен-Жозеф-де-Силлери близ Квебека, а затем и в Ля Консепсьон в Труа-Ривьер. В перспективе редукционная система привела к полной ревизии программы «францизации», как ее понимал Шамплен и большинство других представителей колониальных властей, в иезуитском апостолате в Новой Франции.

Главной задачей, стоящей перед иезуитами при создании редукций, было обеспечение условий для перехода христианских индейцев к земледелию. Однако с самого начала поселения неофитов в Силлери миссионеры были вынуждены корректировать свои первоначальные замыслы, приспосабливаясь к индейским традициям. Например, при закладке полей неофиты следовали своим обычаям, располагая их на холмах, а не в долинах, что препятствовало их обработке с помощью животных по европейскому образцу. Поля обрабатывались преимущественно женщинами, которые были традиционными земледельцами в аборигенных обществах Вудленда [9, р.62]. Точно так же туземные христиане отказались жить зимой в каменных домах, построенных в редукции, так как в них было намного холоднее, чем в деревянных домах или их традиционных хижинах из коры [25, Т. I, p. 203-204].

При получении прав собственности на Силлери в 1638 г. иезуиты констатировали, что большая часть тамошней земли непригодна для сельского хозяйства. Более того, это был самая северная граница ареала маиса в Канаде, что отражалось на количестве и качестве урожая. Действительно, эта лесистая местность потребовала нескольких лет распашки, прежде чем в 1640 г. была посажена первая кукуруза [15, Vol. XVIII, p. 109]. Иезуиты активно помогали бывшим кочевникам в освоении новых сфер деятельности: «Преподобный отец Вимон, супериор миссии, - сообщала мать Мари л'Энкарнасьон в сентябре 1640 г., чтобы воодушевить своих бедных дикарей, сам ведет их к работе и работает на земле вместе с ними» $[25, \mathrm{~T}$. I, p. 68]. В течение нескольких лет сельскохозяйственная практика в Силлери, вероятно, приносила мало результатов, так как иезуиты не упоминали об урожаях. Тем не менее в 1644 году отец Вимон уверял, что «прекрасные початки маиса», представленные неофитами в часовне Силлери, произведены на землях редукции [15, Vol. XXV, p. 221]. В 1646 г. они обрабатывали уже до 15 арпанов земли [15, Vol. XXVIII, p. 185]. Сельскохозяйственная практика становится, следовательно, постоянной, но ее продуктов недостаточно жителям редукции, которые продолжали зависеть от охоты и рыболовства.

Это отчетливо видно при анализе календаря деятельности в Силлери, который полностью соответствовал ритмам сезонной охоты и с которым иезуиты в конце концов были вынуждены смириться. Вимон в 1643 г. прямо заявлял, что «христианские Дикари» живут в редукции «весь год, кроме времени охоты». Поздней осенью или в начале зимы взрослое население рассредотачивалось маленькими семейными группами по огромному пространству долины реки Св. Лаврентия для зимней охоты. «К концу апреля все 
Дикари снова собираются вместе... Когда земля совсем освобождается от снега, все идут на свои поля и начинают работать на них» [15, Vol. XXIII, p. 303, 317; Vol. XXVIII, p. 153, 185; Vol. XXX, p. 157, 165]. Ключевыми моментами жизни редукции были отправление и возвращение охотников - после замерзания рек осенью и таяния весной. Этот календарь соответствовал и ритму торговли, так как корабли, доставлявшие товары из Европы, уходили до замерзания вод, чтобы вернуться только в начале лета [15, Vol. XXV, p. 161; Vol. XXX, p. 165, 195].

Сохранение номадизма сильно усложняло задачу миссионеров: они были вынуждены следить не за большой общиной, а за множеством охотничьих групп. Кроме того, охота часто нарушала сельскохозяйственный ритм: если зимняя охота была неудачной, ее дополняли летними экспедициями в отдаленные области, в ущерб работе на земле [15, Vol. XXIII, p. 319; Vol. XXXII, p. 95]. Ожидая прибытия кораблей из Франции, индейцы скорее стремились подготовиться к обмену мехами вместо того, чтобы заняться работой, результат которой будет лишь осенью.

Еще более остро проблема «доместикации» канадских индейцев и бесперспективность «францизации» обнажились в несельскохозяйственных районах залива Св. Лаврентия и к северу от одноименной реки, где обитали кочевые племена монтанье. Экономическим и административным центром этой области был Тадуссак, старейшая французская фактория в Канаде, возникшая еще в конце XVI в. В первой половине XVII в., несмотря на освоение долины р. Св. Лаврентия, Тадуссак оставался главным портом, куда ежегодно приходили французские корабли, и местные группы монтанье контролировали торговлю племен, живущих севернее от них - по р. Сагеней и оз. СенЖан [26, с. 47]. Не желая терять выгодную позицию посредников во франко-индейских торговых отношениях, монтанье Тадуссака, согласившись креститься в 1640-1641 гг., тем не менее отказались переселиться в редукции. По сути, иезуитская миссия в Тадуссаке означала ежегодный сбор множества семейных групп монтанье, приходивших сюда летом ко времени появления кораблей. После торга и духовного наставления туземцы возвращались на свои охотничьи территории. Миссионеры, в свою очередь, были вынуждены приспосабливаться к этому распорядку: назначенный в эту миссию в 1642 г. о. Жан Декон весной отправлялся в Тадуссак из Силлери, «служа французам, которые приплывают туда, и посвящая свою энергию обращению Дикарей», а осенью возвращался обратно [15, Vol. XXIV, p. 127-129; Vol. XXVI, p. 103; Vol. XXXVII, p. 185].

Одновременно с началом христианизации монтанье Тадуссака началась миссионерская деятельность и среди родственных им по языку аттикамек, обитавших у истоков р. Сен-Морис. Первые представители этого народа появились в орбите иезуитского влияния еще в 1637 г., придя в Труа-Ривьер для торговли, и с тех пор периодически посещали этот пост, получая там наставление от местных миссионеров. На их призыв осесть в редукции аттикамек ответили, что они «очень хотят получить наставление и возделывать землю, но не с алгонкинами», уже обитавшими там, которые отличались по «темпераменту» и языку [15,
Vol. XVIII, p. 113]. Они предпочитали, чтобы миссионеры посещали их собственную страну, в дне пути вверх по реке от Труа-Ривьер, на что иезуиты были вынуждены согласиться, как и в случае с монтанье Тадуссака. Второй немаловажной причиной отказа аттикамек от поселения в Ля Консепсьон был страх перед нападениями ирокезов в долине р. Св. Лаврентия, участившихся к началу $40-х$ гг.

Основание миссий в Тадуссаке и у аттикамек демонстрировало новые установки французских иезуитов в вопросе о необходимых основах христианизации язычников: согласие на условия этих групп монтанье означало отказ не только от распространения редукционного проекта на все племена Св. Лаврентия, но и принципиальный отказ от программы «францизации». В Тадуссаке или на Сен-Морис не было постоянного французского населения, это были отдаленные районы, следовательно, они были лишены того цивилизаторского влияния, которое считалось необходимым для христианизации «дикарей». Они также были абсолютно непригодны для сельскохозяйственной деятельности, подобно Силлери или ТруаРивьер. Таким образом, перед аттикамек и монтанье Тадуссака к 1641 г. не ставилось задачи перехода к оседлому образу жизни, то есть к «цивилизации», а номадизм тем самым признавался совместимым с христианским образом жизни [15, Vol. XXI, p. 95].

C 1647 г. миссионеры (Ж. Декон, Г. Дрюйет, П. Беллоке и Ш. Альбанель) начали ежегодно сопровождать неофитов в их зимних охотничьих кочевьях к северу от р. Св. Лаврентия, «выполняя работу, которая, воистину, могла бы сломить тело Гиганта» [15, Vol. XXX, p. 195, 197; Vol. XXXII, p. 259]. Однако согласие иезуитов с кочевым образом жизни их паствы вовсе не означало признание его достоинств и тем более его превосходства над оседлым. И во второй половине столетия в Реляциия часто появлялись пассажи, в которых жизнь кочевых племен сравнивалась с «жизнью зверей», и не оставлялись попытки их «доместикации» [15, Vol. XLVIII, p. 71; Vol. LIV, p. 139].

В результате признания к середине XVII в. номадизма приемлемым образом жизни для обращенных туземцев иезуиты окончательно отказались от попыток «францизировать» индейцев Канады. В Реляции 1646 г. новый супериор канадской миссии Ж. Лалеман выражал идеи, абсолютно противоположные тем, которые десять лет назад провозглашал Лежён: хотя индейцы и «начинают считать, что для того, чтобы быть добрыми христианами, они должны жить во всем по-французски», однако «простоватая искренность предпочтительней притворной любезности; избыток никогда не был благ; если эти добрые неофиты примут это [поведение], то они скоро устанут от него» [15, Vol. XXIX, p. 127-129]. Таким образом, иезуиты действительно приступают к реализации своей собственной миссионерской программы в Новой Франции, основанной на опыте нескольких десятков лет работы на миссионном поле, а не на заранее сформулированных концепциях.

Дж. Экстелл прямо называет создание миссий в Тадуссаке и у аттикамек главной причиной «изменения иезуитами своей конверсионной политики» в 1640 г. Приспосабливаясь к монтанье, миссионеры признавали за кочевыми охотниками возможность 
стать «хорошими христианами», и возможность аккомодации христианского учения и образа жизни ко многим важным аспектами традиционной культуры. Возможно, они надеялись, что их приспособление к европейской цивилизации будет медленным и постепенным, но сами они оставили всякие попытки ускорить этот процесс. Туземцы сохраняли свой язык, свои социальные структуры, свои формы правительства, свою политическую и военную автономию и свой образ жизни, за исключением того, что прямо противоречило христианской вере $[9$, р. 61, 62, 276]. В результате редукционная программа в долине p. Св. Лаврентия, едва возникнув, была дополнена программой сезонных кочевых, так называемых «летучих миссий», что получило свое своеобразное отражение и в миссии среди оседлых гуронов, где в то же время возникает и постоянная резиденция СентМари («редукция»), и множество «летучих миссий» в отдаленные поселения гуронов и к соседним с ними народам.

Вместе с тем, кажется неправомерным столь абсолютизировать эти, в целом, ситуационные факторы (основание «летучих миссий» у монтанье) как главную причину модернизации иезуитами их миссионной программы. На наш взгляд, более фундаментальными факторами стали количественный рост иезуитского персонала (чего никогда не было у реколлектов, почему они были вынуждены опираться на колониальный ресурс в своем апостолате) и повышение уровня знаний миссионеров о новых племенах и разных аспектах туземной культуры. В 1645 г. гуронский супериор Ж. Лалеман мог утверждать, что «нам очень легко толковать им [индейцам] истины нашей Веры, хотя вначале нам казалось самым трудным объяснить [их]» [15, Vol. XXVIII, p. 65]. Многочисленные иезуитские миссионеры могли входить в контакт с большим количеством индейских народов, используя широкий спектр аккомодационных методов для их христианизации. Зависимость миссионеров от светских колониальных проектов слабела по мере усиления их влияния в колонии и среди множества племен, посредниками в отношениях между которыми они стали.

Громадное значение в переоценке иезуитскими миссионерами в Новой Франции колониальных цивилизаторских установок имели морально-нравственные издержки интенсификации франко-индейского контакта, проявившиеся, в первую очередь, в алкоголизме и распущенности, в результате которых, как правило, следовало религиозное падение и отступничество [см.: 27].

Спиртные напитки уже к началу XVII в. превратились в одну из ключевых статей мехового бартера по всей Северной Америке. При этом индейцы не обладали стойким иммунитетом не только ко многим европейским инфекционным заболеваниям, но и к алкоголю. Зависимость наступала очень быстро и сопровождалась трагическими последствиями: нищетой, насилием, социальной, моральной и физической деградацией и, наконец, ранней смертью. Сообщения из колонии в течение столетия были наполнены описаниями ужасов, творимых туземцами в пьяном состоянии: «убивающими друг друга, мужьями, сжигающими своих жен, женами, позорящими мужей, отцами, бросающими своих детей в кипящие котлы» [28, p. 8].
К 40-м гг. миссионеры были убеждены, что пьянство среди туземцев является одним из главных препятствий для их обращения и сохранения в вере [15, Vol. XXVIII, p. 31, 37; Vol. XLVIII, p. 63]. Супериор канадской миссии о. Лемерсье заявлял в 1668 г., что есть только «один демон, а именно пьянство, который причиняет больше вреда, чем все демоны вместе», и выражал уверенность, что «Ангел может быть сделан из Варвара, если оградить его от бренди, ибо мы слишком хорошо знаем из опыта, что он превращает христиан в отступников и разрушает самые прекрасные надежды на наши младенческие церкви» [15, Vol. LI, p. 267-269]. Обращает внимание тот факт, что к этому времени иезуиты пытались из индейцев «делать ангелов», а не французов.

Результатом стало проведение иезуитскими миссионерами изоляционистской политики в отношении туземных неофитов. С 50-х гг. миссионеры редукций, по сути, отказались от одного из основополагающих принципов как «францизации», так и оригинального редукционного проекта - оседлого образа жизни. Вместо него были возрождены «летучие миссии», то есть сопровождение миссионерами своей паствы в ее кочевье в течение охотничьего сезона [15, Vol. XXXVI, p. 193-195]. Воспринимаемую прежде варварской чертой, иезуиты восхваляли кочевую жизнь, указывая, что «общение с животными менее вредно, чем с людьми», так как «в городах порок правит более, чем в лесах» [15, Vol. XLVII, p. 167-169]. Охотничьи экспедиции казались меньшим злом, ибо удаляли неофитов от разлагающего воздействия колониальных центров. В 1667 г. Журнал иезуитов сообщал, что миссионер редукции Кап-де-ля-Мадлен о. Николя «ушел на два или 3 месяца вглубь страны с алгонкинами, чтобы удалить их от искушения пьянства, котоpoe больше, чем когда-либо» [15, Vol. L, p. 207]. В следующем году супериор миссии Лемерсье в пассаже о христианских монтанье района Тадуссака замечал, что «их отдаленность от французов освобождают их от этого зла» [15, Vol. LVI, p. 267]. Некогда казавшаяся миссионерам абсолютно необходимой совместная жизнь индейцев и европейцев как условие не только «цивилизации», но и христианизации уже воспринималась как одно из главных препятствий духовному развитию неофитов.

Важнейшим следствием отказа от программы «францизации» стала концентрация усилий иезуитов на исключительно религиозном обращении индейцев и моральной реформе тех туземных обычаев, которые нарушали важнейшие католические нормы, вроде многоженства или развода. Миссионеры с равной готовностью реализовывали эти цели и в редукциях, основанных близ французских поселений, и в сотнях километрах от них, в сердце племенных обществ, причем со временем укреплялась тенденция к изоляции реальной и потенциальной паствы от чаще тлетворного, нежели благого влияния европейской цивилизации. В конце концов принадлежность к той или иной культуре становилась не столь важной, если эти культуры проникнуты христианской религией. По мнению о. Ж. Лалемана, «милость Божья», которую могут обрести лишь верные христиане, делает терпимыми грехи, приписываемые индейцам: «Я не удивлен, что у тех, кто не понимает Дикарей и кто не может проникнуть в их мысли, нет никакого уважения к 
ним. Они свободны и независимы до крайней степени; у них нет ни утонченности, ни цивилизованности французов. Только чистая благодать, которую Бог дарует им, делает их привлекательными; теперь эта благодать известна только тем, кто смотрит в их души» [15, Vol. XXXII, p. 249]. К середине 40-Х гг. торжество религиозно-нравственных оснований иезуитского апостолата проявилось окончательно: Рагено утверждал в 1646 г., что «поистине их вера - работа одного лишь Бога и что рука его простерта над этим Новым Светом не меньше, чем над остальной частью земли» [15, Vol. XXX, p. 73].

Выводы исследования и перспективы дальнейтих изысканий данного направления. Таким образом, эволюция отношения иезуитских миссионеров к программе «францизации» коренного населения Новой Франции, от полного принятия ее положений в начале XVII в. до фактически полного отказа от них во второй половине столетия, по крайней мере де-факто, отражает основные этапы развития миссионерской деятельности ордена в Канаде. Начиная миссионерское предприятие в 1611-1630 гг. в Акадии и Квебеке, иезуиты столкнулись с проблемами начального освоения колониальной территории, решить которые они могли лишь в полном согласии с представителями светской власти. Перед последними стояла задача создания стабильной сельскохозяйственной колонии с многочисленным населением. В результате отсутствия интенсивной эмиграции из метрополии эту задачу пытались решить посредством ассимиляции и аккультурации коренного населения, что и получило название «францизация». В миссионерском контексте это означало приоритет цивилизации перед христианизацией.

По мере расширения иезуитского апостолата среди различных индейских племен и укрепления позиций миссионеров как основных посредников во франкоиндейских отношениях к середине XVII в., с одной стороны, и ростом противоречий между иезуитами и колонистами и колониальной властью по широкому спектру проблем (включая тлетворное влияние европейских культурных и поведенческих паттернов) - с другой, миссионеры постепенно отходят от первоначальных трактовок целей и задач христианизации. На смену задачам «цивилизаторства» приходят чисто религиозная трактовка конверсии, предполагавшая приоритет религиозного обращения перед культурным.

\section{СПИСОК ЛИТЕРАТУРЫ:}

1. Eccles W.J. France in America. N. Y.: Harper \& Row, 1972. 297 p.

2. Trudel M. The Beginnings of New France, 15241663. Toronto: McClelland and Stewart, 1973. 323 p.

3. Campeau L. La Mission des Jésuites chez les $\mathrm{Hu}-$ rons, 1634-1650. Montréal: Éditions Bellarmin, 1987. $488 \mathrm{p}$.

4. Campeau L. The Jesuits and Early Montreal. Midland: Steve Catlin, 2002. $181 \mathrm{p}$.

5. Documents relative to the colonial history of the State of New York: procured in Holland, England and France / ed. by E. B. O'Callaghan. Albany: Weed, Parsons \& Co, 1856. Vol. I. 772 p.

6. Jaenen J.C. Problems of Assimilation in the New France, 1603-1645 // French Historical Studies. Spring, 1966. Vol. 4, № 3. P. 265-289.
7. Jaenen J.C. The Frenchification and Evangelization of the Amerindians in the Seventeenth Century New France // Canadian Catholic Historical Association Study Sessions. 1968. Vol. 35. P. 57-71.

8. Jaenen J.C. Education for Francization: The Case of New France in the Seventeenth Century // Indian Education in Canada. Vol. 1: The Legacy / ed. by J. Barman, Y. Ibert, D. McCaskill. Vancouver, The University of British Columbia Press, 1986. P. 45-63.

9. Axtell J. The Invasion Within: The Contest of Cultures in Colonial North America. N. Y., Oxford University Press, 1985. 389 p.

10. Ronda J.P. The European Indian: Jesuit Civilization Planning in New France // Church History Sept. 1972. Vol. 41, № 3. P. 385-395.

11. Stanley G.F.G. The Policy of «Francization» as Applied to the Indians During the Ancien Regime // Revue d'histoire de l'Amerique francaise. Dec. 1949. Vol. III. № 3. P. 333-348.

12. Campeau L. Les Cent-Associés et le peuplement de la Nouvelle-France (1633-1663). Montréal, Bellarmin, 1974. $174 \mathrm{p}$.

13. Campeau L. Catastrophe démographique sur les Grands Lacs - Les premiers habitants du Québec. Montréal, Bellarmin, 1986. $147 \mathrm{p}$.

14. Monumenta Novae Franciae / ed. par L. Campeau. Roma, Québec, Bellarmin, 1967-2003. Vol. I-IX.

15. The Jesuit Relations and Allied Documents. Travels and Exploration of the Jesuit Missionaries in NewFrance, 1610-1791 / ed. by R.G. Thwaites. Cleveland, The Burrows Brothers Company Publishers, 1896-1901. Vol. I-LXXII.

16. Lescarbot M. The history of New France. Toronto, Champlain Society, 1907-1914. Vol. I-III.

17. Édits, ordonnances royaux, déclarations et arrêts du Conseil d'État du roi concernant le Canada. Québec, Fréchette, 1854.648 p.

18. Лортц Й. История Церкви [Электронный реcypc] // http://krotov.info/history/04/rudokvas/lortz04.html.

19. Goddard P.A. Augustine and the Amerindian in Seventeenth-Century New France // Church History. Dec. 1998. Vol. 67. Issue 4. P. 662-681.

20. Goddard P.A. Science and Scepticism in the Early Mission to New France // Journal of the Canadian Historical Association / Revue de la Société historique du Canada. New series. 1995. Vol. 6. № 1. P. 43-58.

21. Sagard G.T. Histoire du Canada et voyages que les Freres Mineurs recollects y ont faicts pour la conversion des infideles depuis l'an 1615. Avec un dictionnaire de la langue huronne. Paris, E. Tross, 1866. Vol. I-II.

22. Le Clercq C. First establishment of the faith in New France. N. Y., J. G. Shea, 1881. Vol. I-II.

23. Champlain S. de. The works of Samuel de Champlain / ed. by H.P. Biggar. Toronto, Champlain Society, 1922-1936. Vol. I-VI.

24. Scriver C.R. Human Genetics: Lessons from Quebec Populations // Annual Review of Genomics and $\mathrm{Hu}-$ man Genetics. September 2001. Vol. 2. P. 69-101.

25 . Lettres de la révérende mère Marie de l'Incarnation (née Marie Guyard): première supérieure du monastère des Ursulines de Québec. Paris, Librairie internationale catholique, 1876 . T. I-II.

26. Аверкиева Ю.П. Индейцы Северной Америки. От родового общества к классовому. М., Наука, 1974. 349 c. 
27. Федин А.В. Борьба иезуитов с индейским алкоголизмом в Новой Франции в XVII в. // Вопросы истории. 2016. № 2. С. 68-86.

28. Belmont, abbé. Histoire de l'eau-de-vie en Canada, ca. 1705 // Historical Documents. 1st Series. Vol. 2, No. 8. Quebec, 1840.29 p.

29. Smillie-Adjarkwa C. Aboriginal Alcohol Addiction in Ontario Canada: A Look at the History and Cur- rent Healing Methods That Are Working In Breaking the Cycle of Abuse // Indigenous Policy Journal. Fall 2009. Vol. XX. No. 3. P. 1-9.

30. Denys N. The description and natural history of the coasts of North America (Acadia) / ed. by Ganong W.F. Toronto, Champlain Society, 1908. 657 p.

\section{ACCULTURATION STRATEGIES: A POLICY OF FRANCIZATION IN A CONTEXT OF JESUIT MISSION IN NEW FRANCE IN FIRST HALF OF THE XVII CENTURY} (C) 2016

A.V. Fedin, candidate of history sciences, associate professor of General History, International Relations and International Law Department Bryansk State University, Bryansk (Russia)

Abstract. Formation of the difficult and branched out network of the unions with the American Indian tribes, based on mutually advantageous economic and military-political relations was one of the main features of the French colonial regime in Canada of XVII century. As a result, in the first decades of XVII century the most outstanding representatives of secular and spiritual colonisation of New France (Champlain, Recollects and Jesuits) started working out the most effective strategy of Franco-Amerindian rapprochement and the cooperation, embodied in the program «francization», i.e., ideas of acculturation and assimilation of the native population of Canada by Frenchmen as basic means of social and economic and political development of a colony. Catholic missionaries including members of a Jesuit order were interested in realisation of this program at the initial stage of development of new territories and formation of a colonial infrastructure, as material basis of their apostolate activity among the American Indian peoples. From this point of view, «Civilisation» of Indians on the French sample was considered priority in relation to Christianization. In the process of Jesuit mission network expansion among the cores of trading and military colony partners and the Jesuit missionary transformation into the main intermediary in Franco-Amerindian relations in the middle of XVII century, on the one hand, and growth of contradictions with the secular colonial power on a wide spectrum of problems (including trade in alcoholic drinks), Jesuits began to audit initial positions of the «francization» program, resulted in 2 nd half of the century to full refusal of them and the statement of a primacy of the religious reference over the cultural.

Keywords: Catholic church; Jesuits; missionary activity; New France; Quebec; Acadie; North American Indians; Algonquins; Hurons; Iroquois; assimilation; acculturation; accommodation; francization; colonisation; alcoholism; epidemics; fur-trade; reductions.

УДК 94(470.66)Т-50

\section{БЕЙ-БУЛАТ ТАЙМИЕВ - ВЫДАЮЩИЙСЯ ВОЕННО-ПОЛИТИЧЕСКИЙ ДЕЯТЕЛЬ ЧЕЧНИ ПЕРВОЙ ТРЕТИ ХІХ ВЕКА}

(C) 2016

\section{P.A. Товсултанов, кандидат исторических наук, доцент кафедры новой и новейшей истории Чеченский государственный университет, Грозный (Россия)}

Л.Н. Галимова, доктор исторических наук, профессор кафедры гуманитарных и социальных дисциплин Ульяновский институт гражданской авиации имени главного маршала авиации Б.П. Бугаева, Ульяновск (Россия)

Аннотащия. В настоящей статье проведен анализ военно-политической обстановки в Чечне, сложившейся в конце XVIII - первой четверти XIX вв. Отмечается, что кризис военно-политической обстановки в Чечне происходит после того, как в начале XIX века к России был присоединен ряд областей и государств Закавказья. Теперь установление эффективного контроля над непокоренными горцами превращается для царизма из задачи сугубо пограничной в задачу стратегическую. Выполнение ее было поручено генералу А.П. Ермолову, который все свое внимание обращает на Левый фланг (куда входила и Чечня) Кавказской линии. И с этого времени приоритетным направлением в его действиях становится Чечня. Ермолов сразу же стал проводить жесткую политику по отношению к горцам, частыми становятся карательные экспедиции с целью устрашения чеченцев. Такая политика А.П. Ермолова постепенно привела к консолидации различных чеченских обществ, прежде разделенных на кланы и племена. Доведенные до отчаяния жесткой политикой кавказского наместника чеченцы в 1825 г. поднимают восстание. Возглавил объединительное движение Бей-Булат Таймиев. В статье исследуется восстание Бей-Булата Таймиева в 1825-1826 гг., отмечаются причины и характер движения горцев, проанализированы причины поражения и итог восстания. Оцениваются роль и значение Бей-Булата Таймиева в истории Чечни.

Ключевые слова: Чечня; царизм; военно-политическая обстановка; царская администрация; восстание; горцы; политика России; сопротивление; восставшие; царские войска; военный поход; движение горцев; Дагестан; Кавказ; непокорные горцы; консолидация; уничтожение; наместник; царская власть; всеобщее восстание; Северный Кавказ; чеченцы; репрессивная политика. 